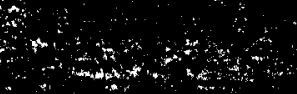

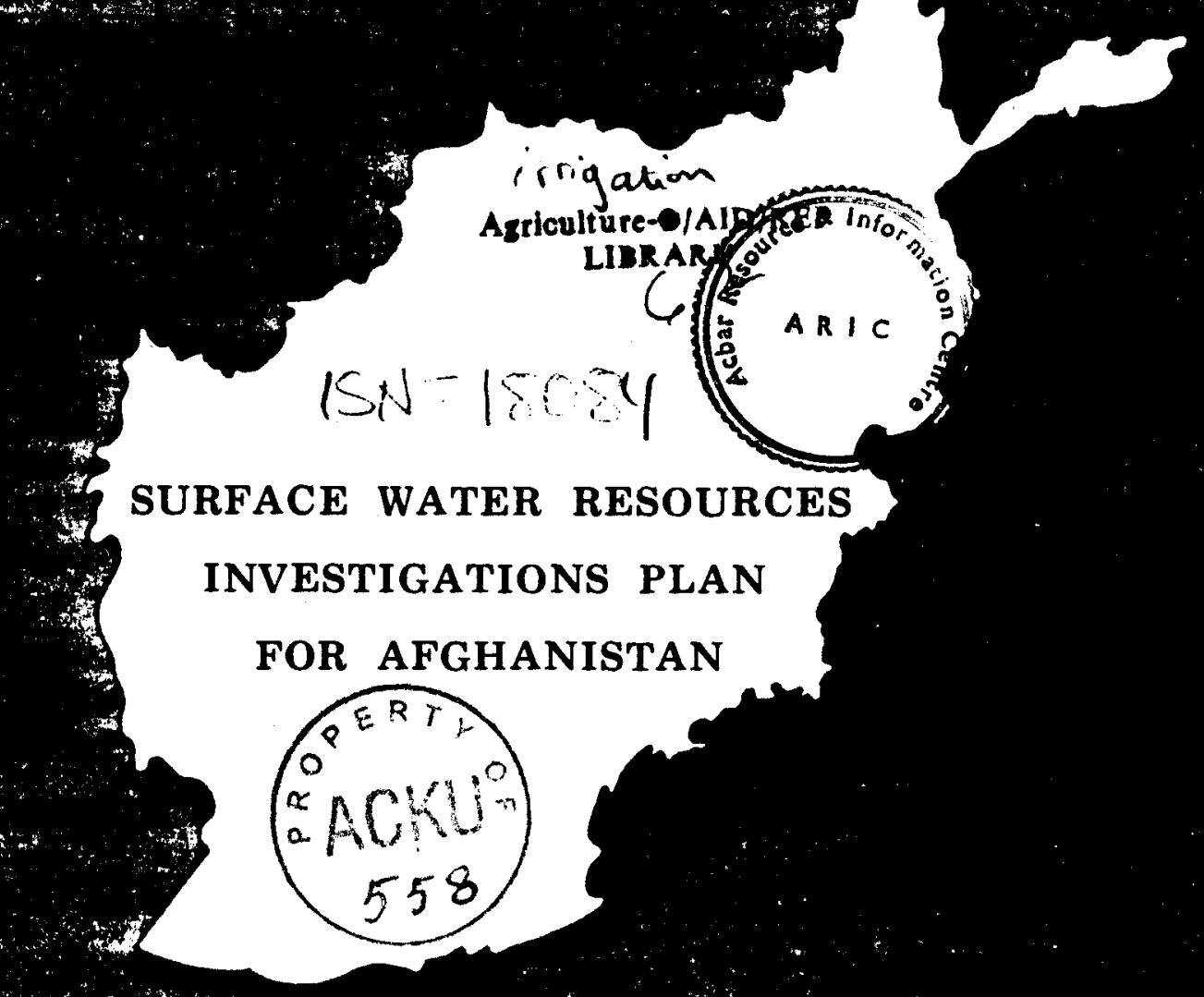

Prepared cooperatively by

the United States Geological Survey and the Water and Soil Survey Department, Ministry of Agriculture and Irrigation, Royal Government of Afghanistan under the auspices of the United States Agency for International Development 
Surface Water Resources

Investigations Plan

for Afghanistan

by
Agriculture-O/AID/REP LIBRARY

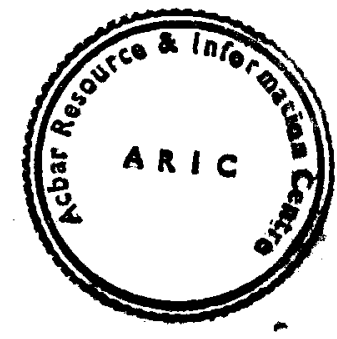

A. O. Westfall and V. J. Latkovich

Water Resources Division

U.S. Geological Survey

Administrative Report

Kabul, Afghanistan

June 1966 


\section{Contents cont'd}

Page

Need for Water Data . . . . . . . . . . . . . . 16

Hydrology . . . . . . . . . . . . . . . . . . 16

Hydroelectric Power . . . . . . . . . . . . . . . 17

Irrigation . . . . . . . . . . . . . . . . . 19

Flood Control . . . . . . . . . . . . . . . . . 21

Water Supply ................. . 23

International Rivers . . . . . . . . . . . . . . 24

Water Law . . . . . . . . . . . . . . . . 25

Investigation of Surface-Water Supplies . . . . . . . . . 26

Evaluation of Surface-Water Data Collection Program . . . . . 28

Organization . . . . . . . . . . . . . . . . . 28

Central Agency ................. . . 28

Hydrologic Teams ................... 29

Present Gaging Station Network . . . . . . . . . . . 30

Fleld Work . . . . . . . . . . . . . . . . 33

Office Work ..................... . . 34

Recommendations . . . . . . . . . . . . . . . 35

Organization . . . . . . . . . . . . . . . . . . 35

Proposed Gaging Station Network . . . . . . . . . . 36

Primary Gaging Stations . . . . . . . . . . 36

Secondary Gaging Stations . . . . . . . . . 36

Water-management Stations . . . . . . . . . 37 
Contents

Page

Abstract . . . . . . . . . . . . . . . . . . . 1

Introduction . . . . . . . . . . . . . . . . . 2

History . . . . . . . . . . . . . . . . 2

Purpose and Authority . . . . . . . . . . . . . . 3

Acknowledgments . . . . . . . . . . . . . . . . . 4

Afghanistan . . . . . . . . . . . . . . . . . . . 5

General Description . . . . . . . . . . . . 5

Climate . . . . . . . . . . . . . . . . . 6

Temperature ................. 6

Preclpitation ................ 6

River Systems . . . . . . . . . . . . . . . . . II

Oxus River..................... 11

Helmand Rlver ................. 12

Kabul River .................. . . 12

Hari River . . . . . . . . . . . . . . 13

Minor Systems . . . . . . . . . . . . . 13

Transportation and Communication ............ 14

Roads . . . . . . . . . . . . . . . 14

Waterways . . . . . . . . . . . . . 14

Airways .. . . . . . . . . . . . . . . 14

Communication . . . . . . . . . . . . . . . 15 
Illustrations

Page

Figure 1.--Map of Afghanistan Showing (present and proposed)

Stream-Gaging Network . . . . . . . . . . . In Pocket

2.--Recommended Staffing Pattern . . . . . . . . 47 
Contents cont'd

Page

Partial-record Stations . . . . . . . . . . 37

Reservolr and Stace Stations ......... 38

Benchmark Stations ............. . 38

Procedures and Standards . . . . . . . . . . 42

Fleld................... 42

Office .................... 44

Special Investigations . . . . . . . . . . 44

Personnel .................... . . . 46

Size of Staff................ . . 46

Disclplines................. . . . 46

Present Staff................. 48

Participant Training . . . . . . . . . . 49

In-service Training . . . . . . . . . . . 49

Equipment and Supplies . . . . . . . . . . . . 51

Hydrologic . . . . . . . . . . . . . . 51

Transportation ............... . . 51

Maintenance . . . . . . . . . . . . 52

Office ......................... 52

Publications and Ilbrary . . . . . . . . . . . . 54

Basic data ................. 54

Library . . . . . . . . . . . . . . . 55

References . . . . . . . . . . . . . . . . 56

Append1x . . . . . . . . . . . . . . . . . . 58 


\section{Tables}

Page

Table 1.--Monthly Mean Temperatures at Selected Stations . . . . 7

2.--Instantaneous Maximum and Minimum Temperatures
and Maximum Precipitation for 24 hours at
Selected Stations........................ 8

3.--Monthly and Annual Precipation at Selected Stations .................... 10

4.--Existing Stream-Gaging Stations . . . . . . . . 31-32

5.--Proposed Stream-Gaging Stations.......... 40-4I

6.--Recommended Participant Training Program ....... . 50 


\section{Abstract}

Surface-water resources investigations in Afghanistan have been carried on since 1946 with the gutdance of Amerlcan engineers. Until 1963, these investigations were confined to streams of the Helmand River Basin. In 1964, however, the U.S. Agency for International development was requested to assist in the organization of a Water and Soll Survey Author Ity in the Government of Afghanistan, and to develop . a plan for a nationwide network of stream-gaging stations that would supply the hydrologic data necessary for increasing agricultural production through irrigation.

Th1s report evaluates the present surface-water data collection program and makes recommendations for the improvement of the central organization, for a gaging-station network to supply needed information, and for procedures and standards under which the organization could operate effectively. 


\section{Introduction}

History.--Surface-water resources investigations in Afghanistan have been conducted by American engineers since 1946 when feasibility studies were undertaken by Morrison Knudsen Company and its affiliates in the Helmand Valley development. In 1952, Mr. I. J. Snell of the U.S. Geological Survey (USGS) arrived to set up a streammgaging program under the auspices of a predecessor of the U.S. Agency for International . Development (USAJD) and in June 1954, Mr. I. A. Heckmiller arrived to assist Mr. Snell. Since that time work has continued under agreements between the USAID, with Mr. R. H. Brigham replacing Mr. Heckmiller in 1959, and Mr. V. J. Latkovich replacing Mr. Brlgham in 1964. From 1952 unt1. 1963, the project was titled, "Helmand Surface-Water Investigations", and activities were confined to the streams of the Helmand Basin.

In March 1963, the Royal Govermment of Afghanistan (RGA) organized an independent agency, the Water and Soil Survey Authority (WSSA), for the collection, interpretation, and publication of data on the water and soils of Afghanistan, and requested assistance of USAID in developing the Surface Water Hydrology Section of WSSA while at the same time continuing the advisory services provided by the former Helmand Surface Water Investigations. The project renamed "Surface Water Research" was made a part of the National Agricultural Development Project of USAID with headquarters In Kabul. With the expanded project, the senior author of this report, arrived in March 1964 to assume leadership. The project has functioned since that time under two full-time advisors. Farly in 1966, the WSSA ceased to function as an independent authority and was taken into the Ministry of Agriculture as the Water and Soil Survey Department (WSSD) 
under the Natural Resources Division.

Another hydrologic mission, the "Deutsche Wasserwirtschafts Gruppe", West German Hydrological Mission (WGHM) of the Federal Republic of Germany, began water resources investigations in 1958, concentrating most of its activities on the surface-water resources of the Kabul River drainage basin. For a short time, the group also worked in the Kunduz River basin but later withdrew to concentrate on work in the Kabul River basin.In the last 2 years, the WGHM has expanded to the Paktia area where some work has been done on the Matun River.

Surface-water investigations have also been carred on by technical aid missions of other countries, notably the Union of Soviet Socialist Republics (USSR) and to some extent, by intermational organizations of the United Nations (UN) and the International Bank for Reconstruction and Development (IBRD). Most of this work has been directed toward obtaining data for specific projects.

Purpose and Authority.--The purpose of this report is twofold: first to evaluate the present gaging station network and to outline the scope of an expanded nationwide stream-gaging network; and second, to recommend procedures, standards, personnel, equipment, and publications needed for operation of the expanded network and dissemination of information to the user.

The Program Agreement (ProAg) between RGA and USAID states that the objective of the project is to advise the RGA, through the Ministry of Agriculture (MinAG), on procedures and practices in surface-water investi- 
gations that will permit the most rational use of the water resources of the country, and further, the ProAg requires the development of a water-resources investigation plan to coordinate the collection of data from drainage basins in all parts of the country.

Acknowledgments--We gratefully acknowledge the cooperation by members of the Afghan Water and Soil Survey Department (WSSD), His Exicellency Mir Mohammad Akbar Reza, formerly President of the WSSA and now Minister of Agriculture and Irrlgation; Mr. Ghulam Sham, Director General of Surface-Water Hydrology (WSSD); Mr. Abdul Khaliq of the Kandahar office of WSSD; other members of the department who have assisted In all phases of the project; the members of the WGHM with whom we have worked amicably in our mutual desire to help Afghanistan in the solution of its water problems; and the members of the UN Speclal Fund Groundwater Investigation Project who have been most helpful in sharing technical knowledge in the "gray" areas between surface-water and ground-water hydrology. 


\section{Afghanistan $1 /$}

\section{General Description}

Afghanistan (fig. I) landlocked in central Asia lies within approximately 30 to 37 degrees north latitude and 61 to 72 degrees east longitude. It has an area of about 635,000 square kilometers, and extends about $1,300 \mathrm{kilometers} \mathrm{from} \mathrm{southwest} \mathrm{to} \mathrm{northeast,} \mathrm{and} \mathrm{about} 600$ k1lometers from northwest to southeast. Afghanistan shares a 2,320 kilometer frontier with USSR on the north, is bordered by Iran on the west and Pakistan on the south. In the "panhandle" of the northeast, Afghanistan touches Communist China's Sinkıang Province.

The majestic Hindu Kush, a spur of the even loftier Himalaya, are the dominant topographical feature of the country. These mountains, which rise in places to more than 6,000 meters, divide the rich plains of the north from the central plateau and southerm deserts. Much of the country is mountainous, with the central plateau having an average altitude of 1,800 meters.

Principal cities include the capital, Kabul, and the provincial cities of Herat, Kandahar, Mazar-1-Sharif, Jalalabad, Shibarghan, Maimana, and Kunduz. Although no nationwide census has ever been taken, the most reliable estimates place the population between 10 and 13 million. A 1965 census of Kabul placed the population of that city at 449,000.

I/ Some of the material in this section is taken from "Afghanistan, a Glimpse", prepared by the United States Information Service, Kabul, Afghanistan. 


\section{Climate}

Temperature.--The climate of Afghanistan is continental, arld to semiarld although a small area near Jalalabad affected by the monsoons of southern Asia is sometimes described as subtropical. The high central plateau has been compared to the Rocky Mountain area near Denver, Colorado in USA although less precipitation is recorded. At an average elevation 1,800 meters on this plateau the days are quite warm but the nights are cool; even in sumer. Winters can be quite severe with subzero temperatures and much snowfall, but the average winter is relatively mild with only short perlods of extreme cold and three or four significant snowfalls. The regions of lower altitude are steppes, or even true desert, with mild winters and hot summers. They are sparsely populated except for scattered cultivated areas where water is avallable for 1rrigation.

Throughout most of Afghanistan, the dally range in temperature is quite wide, both in summer and winter. In the desert areas temperatures sometimes reach $49^{\circ} \mathrm{C}$ during the day but may cool to $15^{\circ} \mathrm{C}$ at night. Temperatures during winter in the northern deserts occasionally drop to $-24^{\circ} \mathrm{C}$ at night but a rise to $10^{\circ} \mathrm{C}$ under the clear skles and warm sun of the daylight hours. The mean temperatures at selected stations are given in table 1. Extremes of temperature and precipitation are shown in table 2.

Precipitation.--Precipitation usually occurs in the perlod extending from the midale of November through May, although in some areas convectional storms may cause precipitation during the summer months. In areas of scant rainfall, it is not unusual for all of the monthly precipitation to occur In a single storm. 


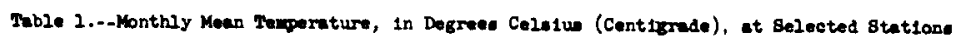

\begin{tabular}{|c|c|c|c|c|c|c|c|c|c|c|c|c|c|}
\hline $\begin{array}{l}\text { 8tation and } \\
\text { Attitude (meters) }\end{array}$ & Year & $\operatorname{Jan}$ & Feb & March & Apri1 & May & June & Juzy & Aus & Bept & Oet & Dor & Dec \\
\hline \multirow{6}{*}{$\underset{1,763}{\text { Tabul }}$} & 1960 & 2.2 & 4.2 & 5.4 & 9.7 & 27.0 & 22.4 & 25.7 & 24.7 & 19.5 & 12.2 & 4.7 & - \\
\hline & 2961 & -0.6 & -2.0 & 6.2 & 21.2 & 29.0 & 23.3 & 25.7 & 24.7 & 21.8 & 12.3 & 4.2. & 0.0 \\
\hline & 1962 & -1.1 & 2.7 & 7.8 & 12.3 & 27.5 & 22.0 & 25.3 & 23.9 & 28.4 & 12.2 & 4.8 & -2.8 \\
\hline & 1963 & -2.2 & 5.9 & 7.4 & 12.4 & 16.1 & 24.5 & 25.2 & 24.2 & 29.5 & 24.3 & 5.6 & 0.9 \\
\hline & 2964 & -21.2 & -4.0 & 5.9 & 31.6 & 26.8 & 22.2 & 24.5 & 24.3 & 29.1 & 21.2 & 4.0 & -1.2 \\
\hline & Ave & -2.4 & 2.5 & 6.6 & 21.4 & 27.3 & 22.8 & 25.2 & 24.3 & 19.6 & 12.4 & 4.6 & - \\
\hline \multirow[t]{6}{*}{$\begin{array}{r}\text { Ierat } \\
975\end{array}$} & 2960 & 2.9 & 7.7 & 6.5 & 23.2 & 29.7 & 27.1 & 28.9 & 27.9 & 22.4 & 20.7 & 7.7 & - \\
\hline & 1961 & 3.3 & 3.4 & 20.8 & 24.2 & 23.3 & 26.7 & 30.3 & 27.5 & 23.8 & 24.8 & 8.7 & 6.7 \\
\hline & 2962 & 2.9 & 8.7 & 12.1 & 25.8 & 22.0 & 25.6 & 30.1 & 26.4 & 20.3 & 24.7 & 6.5 & 5.0 \\
\hline & 1963 & 6.4 & 9.5 & 20.7 & 28.2 & 20.8 & $27 \cdot 7$ & 29.2 & 27.1 & 22.7 & 27.5 & 8.9 & 2.3 \\
\hline & 2964 & -6.7 & 4.9 & 12.8 & 25.4 & 21.6 & 26.7 & 29.5 & 28.1 & 22.1 & 31.5 & 7.9 & -0.3 \\
\hline & Ave & 2.8 & 6.8 & 20.6 & 25.3 & 21.5 & $2 \epsilon .8$ & 29.6 & 27.4 & 22.2 & 25.8 & 7.9 & - \\
\hline \multirow[t]{5}{*}{$\begin{array}{l}\text { Narar-1-Shartif } \\
325\end{array}$} & 1960 & 3.9 & 8.3 & 6.6 & 24.4 & 20.7 & 28.4 & 30.3 & 28.7 & 21.2 & 27.4 & 7.5 & - \\
\hline & 1961 & 3.1 & 3.7 & 21.5 & 25.9 & 25.3 & 28.2 & 32.8 & 28.5 & 23.4 & 13.9 & 8.3 & 5.7 \\
\hline & 1962 & 2.6 & 7.7 & 13.2 & 17.2 & 24.1 & 28.7 & 34.0 & 30.5 & 22.9 & 25.6 & 6.6 & 3.6 \\
\hline & 1963 & 4.3 & 9.6 & 21.2 & 20.2 & 23.5 & 30.8 & 32.5 & 29.8 & 24.3 & 28.9 & 9.2 & 3.0 \\
\hline & 2964 & -3.7 & 6.1 & 12.2 & 26.2 & 23.9 & 30.2 & 32.6 & 30.6 & 24.8 & 23.8 & 9.1 & 0.2 \\
\hline • & Are & 2.0 & 7.2 & 20.9 & 26.7 & 23.5 & 29.2 & 26.2 & 29.6 & 23.3 & 25.9 & 8.2 & - \\
\hline \multirow[t]{6}{*}{$\frac{\operatorname{Manmann}}{900}$} & 1960 & 4.2 & 8.4 & 4.4 & 12.1 & 27.2 & 24.8 & 26.0 & 24.9 & 27.9 & 26.8 & 7.0 & - \\
\hline & 1961 & 3.1 & 1.9 & 8.9 & 23.1 & 21.3 & 24.1 & 27.0 & 24.7 & 19.7 & 2.3 & 8.5 & 6.8 \\
\hline & 1962 & 2.7 & 7.9 & 21.2 & 23.2 & 28.2 & 22.9 & 27.2 & 23.7 & 28.2 & 12.6 & 5.4 & 4.3 \\
\hline & 1963 & 7.1 & 8.9 & 8.7 & 26.4 & 29.6 & 26.5 & 28.0 & 24.6 & 29.8 & 25.2 & 8.6 & 2.7 \\
\hline & 2964 & -3.3 & 4.7 & 20.6 & 13.2 & 18.7 & 24.2 & 27.1 & 25.2 & 29.7 & 20.1 & 9.1 & -0.5 \\
\hline & Ave & 3.2 & 6.3 & 8.7 & 23.6 & 28.9 & 24.5 & 27.0 & 24.6 & 19.0 & 13.2 & 7.7 & - \\
\hline \multirow[t]{6}{*}{$\begin{array}{l}\text { Kendahar } \\
1,007\end{array}$} & 1960 & 5.6 & 31.4 & 31.8 & 27.4 & 23.7 & 30.6 & 31.2 & 26.8 & - & 25.6 & 9.8 & - \\
\hline & 2961 & 4.5 & 6.2 & 24.5 & 27.0 & 26.5 & 31.2 & 32.8 & 29.0 & 25.2 & 25.2 & 20.9 & 6.5 \\
\hline & 2962 & 4.2 & 10.6 & 24.2 & 20.3 & 25.5 & 27.5 & 31.4 & 28.4 & 21.1 & 16.2 & 7.3 & 4.6 \\
\hline & 2963 & 5.9 & 21.6 & 24.3 & 20.4 & 24.7 & 30.9 & 31.2 & 29.4 & 25.9 & 21.7 & 24.5 & 8.8 \\
\hline & 1964 & 2.4 & 8.5 & 27.2 & 20.1 & 24.8 & 28.4 & 32.3 & 30.0 & 23.8 & 24.2 & 9.5 & 3.7 \\
\hline & Ave & 4.3 & 9.8 & 12.3 & 29.0 & 25.0 & 29.7 & 32.3 & 29.1 & - & 16.5 & 20.4 & - \\
\hline \multirow[t]{6}{*}{$\begin{array}{l}\text { Jalajabad } \\
550\end{array}$} & 1960 & - & 24.6 & 24.4 & 28.6 & 27.2 & - & 33.4 & 33.8 & 26.5 & - & - & - \\
\hline & 1961 & $7 \cdot 7$ & - & - & 19.1 & 28.8 & 33.6 & 34.4 & - & 30.9 & 22.4 & 12.0 & 8.4 \\
\hline & 1962 & 7.2 & 11.9 & 26.5 & 21.5 & 27.8 & 32.2 & 33.4 & 32.6 & 26.8 & 21.5 & 13.9 & 7.9 \\
\hline & 1963 & 7.5 & 13.8 & 25.4 & 20.7 & 24.6 & 34.6 & 34.4 & 32.5 & 28.8 & 22.2 & 24.7 & 9.2 \\
\hline & 2964 & 5.6 & 20.0 & 27.4 & 22.4 & 28.2 & 32.4 & 32.5 & 32.9 & 28.2 & 20.9 & 12.3 & 8.6 \\
\hline & Ave & - & - & - & 20.2 & $27 \cdot 3$ & - & 33.6 & - & 28.2 & - & - & - \\
\hline \multirow[t]{6}{*}{750} & 1960 & - & - & - & 28.4 & 24.8 & 32.1 & - & 32.7 & 26.5 & 29.4 & 21.3 & - \\
\hline & 1961 & 6.7 & 7.6 & 25.8 & 28.3 & 27.6 & 31.3 & 34.9 & 31.4 & 27.3 & 18.0 & 21.9 & 9.7 \\
\hline & 1962 & 6.8 & 22.8 & 27.0 & 23.2 & 26.2 & 30.0 & 34.2 & 30.2 & 23.6 & 28.9 & 9.8 & 9.9 \\
\hline & 1963 & 7.9 & 12.8 & 25.3 & 21.9 & 23.8 & 32.2 & 34.2 & 31.6 & 26.9 & 21.6 & 23.2 & 8.2 \\
\hline & 2964 & 2.4 & 9.4 & 16.1 & 20.3 & 26.5 & 31.3 & 33.2 & 31.2 & 24.0 & 24.8 & 21.6 & 3.5 \\
\hline & Ave & - & - & - & 20.4 & 25.8 & 31.4 & - & 31.2 & 25.6 & 28.5 & 31.5 & - \\
\hline
\end{tabular}




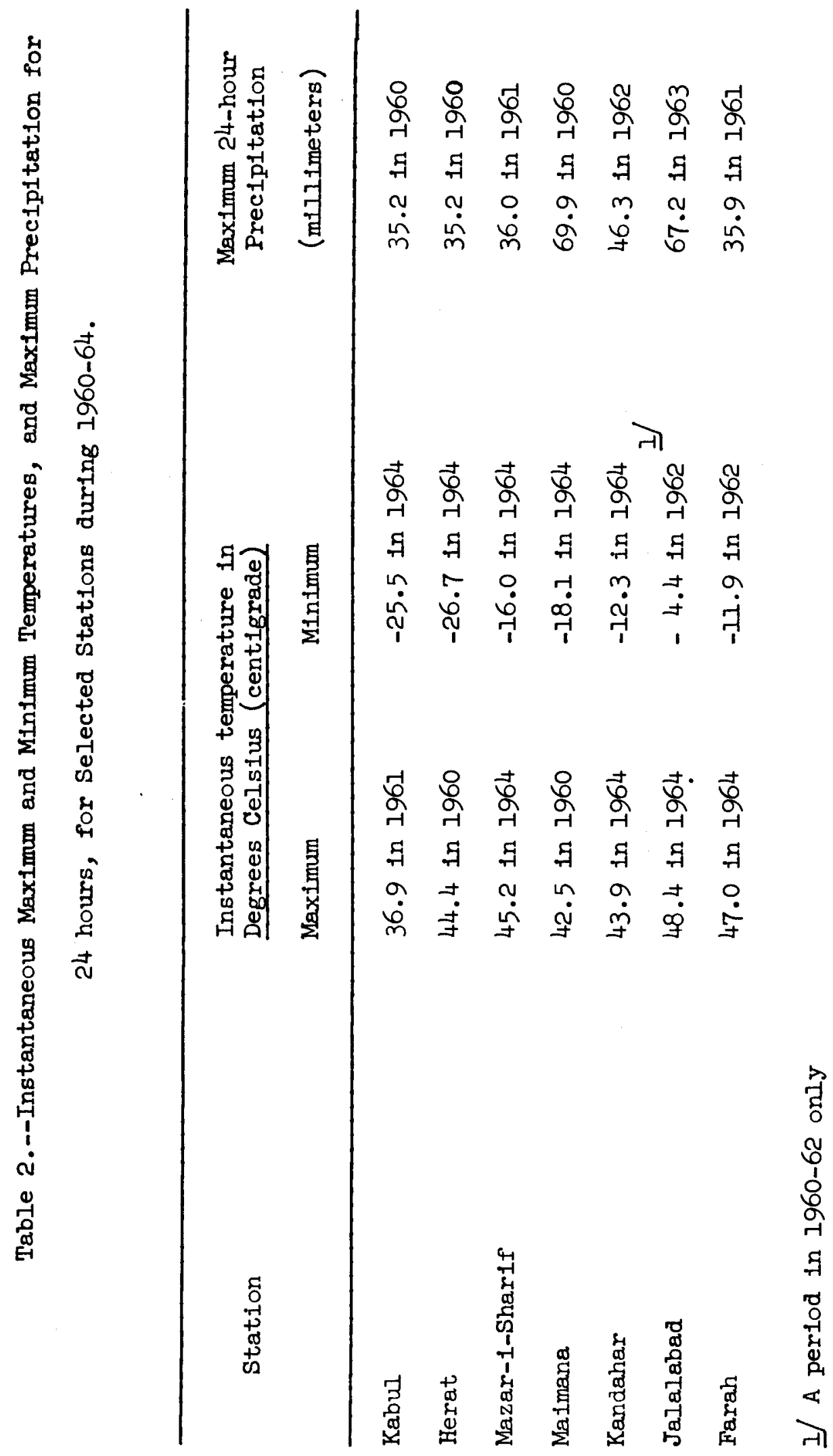


During the winter, relatively large amounts of precipitation fall as snow in the Hindu Kush and across the central plateau. This water is released from storage as snowmelt munof in the spring and summer months. Snowmelt moff is more important to the farmer than rainfall runoff for Irrigating crops and for determining cropping practices. Average precipltation at selected stations is given in table 3 . 
Table 3.+- Wonthly and hanui Precipitation, in kulleters, at selected station

\begin{tabular}{|c|c|c|c|c|c|c|c|c|c|c|c|c|c|c|}
\hline $\begin{array}{l}\text { Btation and } \\
\text { 스t1tude (meters) }\end{array}$ & Year & Jan & Teb & March & Apr1] & Nay & Jume & Jwy & Aug & Bept & Oct & Nor & Dec & Annual \\
\hline \multirow{6}{*}{ Kabur } & 1960 & 11.2 & 32.3 & 54.4 & 176.9 & 12.0 & 0.2 & $\mathbf{T}$ & 0 & $T$ & $\mathbf{T}$ & 40.1 & - & - \\
\hline & 1961 & 22.7 & 42.4 & 101.2 & 127.6 & $\mathrm{u.6}$ & 4.3 & 1.0 & 0 & 0 & 0 & 32.1 & 7.6 & 350.4 \\
\hline & 1962 & 6.8 & 45.6 & 44.3 & 60.4 & 6.5 & 3.7 & $\mathbf{T}$ & $\mathbf{T}$ & $I$ & 5.2 & $T$ & 24.3 & 19.8 \\
\hline & 1963 & 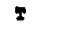 & 45.3 & 55.4 & 108.0 & 104.8 & 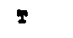 & 0 & 6.4 & 0.6 & 0.8 & 37.6 & 5.3 & 364.2 \\
\hline & 1964 & 67.5 & 106.9 & 74.1 & 218.3 & 13.6 & $\mathbf{T}$ & 6.3 & 0 & $T$ & 0 & 16.2 & 15.2 & 418.1 \\
\hline & Ave & 21.6 & 54.5 & 65.9 & 2128.2 & 29.7 & 1.64 & 1.46 & 1.28 & 0.12 & 1.2 & 25.2 & - & - \\
\hline \multirow{6}{*}{$\begin{array}{l}\text { Borat } \\
975\end{array}$} & 1960 & 16.0 & 64.6 & 59.1 & 66.1 & 6.8 & 0 & 0 & 0 & 0 & 0 & 0.4 & - & - \\
\hline & 1961 & 20.9 & 3.2 & 88.4 & 75.7 & 4.4 & 0 & 0 & 0 & 0 & 0 & 39.4 & 51.7 & 283.7 \\
\hline & 1962 & 9.9 & 20.7 & 39.9 & 32.7 & 5.0 & 0 & 0 & 0 & 0 & $T$ & 7.2 & 15.8 & 131.2 \\
\hline & 1963 & 6.0 & 24.1 & 20.7 & 40.5 & 91.2 & 0 & 0 & 0 & $\mathbf{T}$ & 5 & 13.7 & 30.3 - & 226.3 \\
\hline & 1964 & 23.3 & 95.7 & 62.5 & 37.5 & 0.4 & 0 & 0 & 0 & 0 & 0 & 14.4 & 3.2 & 237.0 \\
\hline & Ave & 15.2 & 39.7 & 54.1 & 50.5 & 21.6 & 0 & 0 & 0 & 0 & 0 & 15.0 & - & - \\
\hline \multirow{6}{*}{$\underbrace{}_{325}$} & 1960 & 22.2 & 26.7 & 48.5 & 88.3 & 24.7 & 0 & 0 & 0 & 0.2 & $T$ & 26.9 & - & - \\
\hline & 1961 & 41.6 & 21.4 & 54.8 & 35.3 & 2.6 & 0 & 0 & 2 & 0 & 0 & 28.5 & 23.2 & 197.4 \\
\hline & 1962 & 16.3 & 47.3 & 21.5 & 45.6 & 5.7 & 0 & 0 & 0 & 0 & 9.4 & 22.9 & 140.5 & 209.2 \\
\hline & 1963 & 6.0 & 22.3 & 46.0 & 67.5 & 33.4 & 1.7 & $T$ & 0 & $\mathrm{~T}$ & 2 & 18.9 & 26.8 & 222.6 \\
\hline & 1964 & $26.0^{\circ}$ & 45.6 & 39.0 & 33.2 & 15.9 & 0 & $\mathbf{T}$ & 0 & 0 & 0 & 16.6 & 2.5 & 178.8 \\
\hline & Are & 22.4 & 28.7 & 42.0 & 54.0 & 16.5 & 0.3 & 0 & 0 & $\mathbf{T}$ & 1.9 & 22.8 & - & - \\
\hline \multirow{6}{*}{$\frac{\operatorname{man}}{900}$} & 1960 & 39.5 & 22.4 & 82.1 & 230.1 & 105.6 & 0 & 0 & 0 & 0 & 4.8 & 42.3 & - & - \\
\hline & 1961 & 68.0 & 59.4 & 124.8 & 92.0 & $14: 7$ & 0 & 0 & 0 & 0 & 0 & 65.0 & 46.9 & 470.8 \\
\hline & 1962 & 32.5 & 72.2 & 57.8 & - & 46.2 & 24.0 & 0 & $\mathbf{T}$ & 0.8 & 35.0 & 22.5 & 31.4 & - \\
\hline & 1963 & 10.6 & 32.0 & $\pi 7 \cdot 3$ & 94.8 & 140.7 & 0 & 0 & 0 & $\mathbf{T}$ & 1.1 & 29.9 & 39.1 & 425.5 \\
\hline & 1964 & 28.7 & 70.0 & 132.0 & 74.8 & 14.9 & 0 & 0.8 & 0 & 0 & 0 & 23.3 & 250.0 & 594.5 \\
\hline & $A v$ & 35.8 & $\cdot 51.2$ & 94.8 & - & 64.6 & 4.8 & 0.2 & 0 & 0.2 & 8.2 & $44 . \overline{6}$ & - & - \\
\hline \multirow{6}{*}{$\begin{array}{l}\text { Kaodanar } \\
1, \infty 07\end{array}$} & 1960 & 6.0 & 3.6 & 40.5 & 56.6 & 0.3 & 0 & 0 & 0 & - & 0 & 0 & - & . \\
\hline & 1961 & 6.1 & 10.6 & 44.8 & 111.0 & 10.7 & $\mathbf{T}$ & 0 & 0 & 0 & 0 & 30.4 & 43.5 & 257.1 \\
\hline & 1962 & 1.0 & 5.4 & 219.6 & 10.2 & $\mathbf{T}$ & 0 & 0 & 0 & 0 & 9 & 0 & 69.7 & 205.9 \\
\hline & 1963 & 3.1 & 5.4 & 90.1 & 59.0 & 68.7 & 0 & 0 & 0 & 0 & 0. & 8.1 & 6.1 & 240.5 \\
\hline & 1964 & 50.8 & 34.7 & 43.4 & 0 & 0 & 0 & 0 & 0 & 0 & 0 & 0.1 & 19.4 & 148.4 \\
\hline & are & 13.4 & 21.9 & 67.7 & 47.4 & 15.9 & 0 & 0 & 0 & 0 & 0 & 7.7 & - & - \\
\hline \multirow{6}{*}{$\frac{\text { Jaluabed }}{550}$} & 1960 & & 4.7 & - & 46.9 & 8.2 & - & 0 & 0 & - & - & - & - & - \\
\hline & 1961 & 26.4 & - & - & 4.0 & - & - & - & - & 0 & 5.0 & 14.8 & 2.1 & - \\
\hline & 1962 & 20.5 & 27.6 & 19.9 & 19.6 & 8.2 & 1.3 & 29.2 & 8.5 & $\mathbf{T}$ & 8.6 & 17.6 & 16.4 & 167.4 \\
\hline & 1963 & 0 & 3.3 & 65.5 & 32.0 & 122.0 & 0.2 & 0 & 1.0 & $T$ & 0.8 & 5.1 & 48.0 & 276.9 \\
\hline & 1964 & 22.4 & 19.2 & 6.1 & 37.2 & 0.6 & $\mathbf{T}$ & $T$ & 2.0 & 0 & 0 & 8.0 & 29.4 & 123.9 \\
\hline & Ave & - & - & - & 35.9 & - & - & $=$ & - & - & - & - & - & - \\
\hline \multirow[t]{6}{*}{ Merin } & 1960 & - & - & - & 33.8 & 2.4 & 0 & 0 & 0 & 0 & 0 & 0.5 & - & - \\
\hline & 1961 & 5.0 & 5.9 & 27.7 & 13.6 & 9.5 & 0 & 0 & 0 & 0 & 0 & $\mathbf{T}$ & 38.9 & 91.1 \\
\hline & 1962 & 0 & 6.2 & 14.1 & 1.1 & $\mathbf{T}$ & 0 & 0 & 0 & 0 & 0 & 0 & 4.0 & 25.4 \\
\hline & 1963 & 1.8 & 14.5 & 29.7 & 23.0 & 25.4 & $T$ & 0 & 0 & 0 & 0 & 6.1 & 1.4 & 101.9 \\
\hline & 1964 & 22.7 & 4.7 & 29.8 & 7.2 & 0 & 0 & 0 & 0.5 & 0 & 0 & 0 & 0 & 95.1 \\
\hline & Ave & - & - & - & 15.7 & $7 \cdot 5$ & 0 & 0 & 0.1 & 0 & 0 & 1.3 & - & - \\
\hline
\end{tabular}




\section{R1ver Systems}

There are about 10 river systems or major subsystems (fig. I) in Afghanlstan of which the Oxus (or Amu Darya), Helmand, Kabul, and Harl Rivers are the most important. Large irrigation and hydropower developments are now under construction or are planned for these basins. It is quite difficult to classify some of the rivers of Afghanistan into systems, because under normal conditions many of them disappear into desert wastes or swampy areas. Of the rivers rising on the northern slope of the Hindu Kush, the Shirln Tagao, Sarepul, Balkh, and Tashkurgan (Kholem) Rivers all disappear in the desert region south of the Oxus River. On the west, the Harl River flows north after leaving Afghanistan and is lost in the desert areas of. USSR. The Helmand and Farah Rivers both flow Into the Hamun or swampy area of the Sistan Basin on the southeastern border.

Oxus River--The Oxus River rises in the high mountain area of the Wakhan Corridor in the northeast where $1 t$ is known as the Pamir River. It flows westward forming much of the border with USSR. Many large tributarles enter the Oxus from the north. The major tributarles from Afghanistan are the Kokcha and Kunduz Rivers. Also, during extreme floods, the Shirin Tagao, Serepul, BaIkh, and Tashkurgan (Kholem) Rivers at times may contribute to the flow to the Oxus. The Oxus River ultimately empties into the Aral Sea in USSR. 
Helmand River--The Helmand River rises on the southerm slopes of the Hindu Kush not far from Kabul. It flows in a southwestward direction until it terminates in the Hamun of the Sistan Basin on the Iranian border where $1 t$ is lost to evaporation. The major tributary to the Helmand River is the Arghandab River that drains a large part of southeastern Afghanistan. The only other major tributary from the east is the Tirin River. Major tributaries from the west are the Musa Qala, Kaj, and Panjao Rivers, and an unnamed tributary that enters the mainstem in the viclnity of Ghizao. Most of the flow orlginates from snowmelt in the high central plateau, and most of the tributarles (except the Musa Qala River and probably the Kaj River) have a relatively high sustained flow throughout the year.

Kabul River--The Kabul River flows from the vicinity of Kabul eastward into Pakistan where 1t enters the Indus River. The major tributary from the south is the Logar River. The bulk of the flow in the lower reaches of the Kabul River comes from the Panshir River that enters the Kabul near Sarob1. The Panshir River originates in the high mountains and has a large sustained flow from snowmelt. Another major tributary, the Kunar River, comes from the mountains of Pakistan and enters the Kabul near Jalalabad. The Laghman River is a minor tributary entering from the north between the Panshir and Kunar Rivers. 
Harl River--The Harl River rises in the high central plateau and flows westward to the Irantan border where it turns northward to form the border between Iran and Afghan1stan. North of Afghanistan it forms the Iranian-USSR border and finally disappears in the desert wastes of Turkmen, USSR. The Kowgon River is the only major tributary to the Har1. This river rises to the south of the Harl River and flows almost parallel to 1 t before joining the Harl near Marwa.

Minor systems--The minor river systems of Afghanistan are the Murghab River in the northwest, of which the Kushka R1ver is a tributary that rlses in Afghanistan but joins the Murghab in Turkmen, USSR; the Adraskand and Farah Rivers on the west which flow parallel to each other and enter the Hamun area of the Sistan Basin from the north and opposite to the Helmand River; the Khash River on the south which rises between the Farah and Helmand Rivers and normally disappears into the desert but occasionally reaches the Hamun; and the many tributarles to the Indus River along the eastern border of which the Matun River is probably the most important except for the Kabul R1ver.

Most of the rivers of Afghanistan have two things in common: fairly steep gradlents in all but the lower reaches, and transport of large silt loads during heavy runoff from rain and snowmelt. 


\section{Transportation and Communication}

Roads--At the present time Afghanistan has a paved road that runs from the port city of Q1zil Qala on the Oxus River south through Kunduz, over Salang Pass to Kabul, then southwest to Kandahar, northwest to Herat, then north to Torghond1 on the USSR border. Some sections of this road have not been completed but are scheduled for completion by the end of the summer of 1966. A paved road runs east from Kabul through Jalalabad" to the Pakistan border near Peshawar, and another paved road runs southeast from Kandahar to the Pak1stan border near Spin Baldak-Chaman. The rest of Afghanistan is covered by a network of rough gravel or dirt roads that connect all the provincial capitals. Some of these roads appear on maps, others do not. Plans are underway to Improve some of these roads.

Waterways--As mentioned previously, the only navigable river is the Oxus on the USSR border, but at present only the USSR is using this river for water transport.

Alrways--Domestic alr service in Afghanistan is provided by the government-controlled Arlana Alrlines. Alrports are available at Kabul, Kandahar, Herat, Maimana, Mazar-1-Shar1f, Kunduz, and Bost. Almost dally service is maintained between Kabul and Kandahar, but not more than twice weekly service exists to the other airports. An alrport exists at Jalalabad but no commerical service is now (1966) offered to that city. A study is underway to determine if all provincial capitals can be connected by alr using Short Takeoff and Landing (STOI) type alrcraft. Some tourlst spots may be included in this network. International service is supplied by 
many airlines to and from Kabul. Ariana Airlines also offers international service at Kandahar as well as at Kabul.

Communication--Limited domestic telephone service exists in the larger cities, between all provincial capitals, and many intermediate points. International telephone service is also available. US AID maintains a radio service between headquarters in Kabul and the facllities at Kandahar and Bost. Afghan Highway Constructors maintains. radio communication between its facilities and to mobile equipment. The Air Authority maintains a large radio communication network for operation of the air lanes. 


\section{Need for Water Data \\ Hydrology}

Hydrology is the study of water. The hydrologic cycle is the circulation of water from the sea to the atmosphere, then back to the sea directly, or by falling on land and flowing to the sea over or under the land surface. Surface-water hydrology is the study of that part of the hydrologic cycle pertaining to the movement of water over the land surface. Knowledge of the hydrology of a country is important, if the full potential of the water resources is to be developed. Logical planning and development cannot take place without first studying the quantity of the water and its occurrence in space and time. The following paragraphs will. describe the categorles of water knowledge that are important to Afghanistan at present, and give a short description of activities in each category. 


\section{Hydroelectric Power}

The importance of electrical power in the modern economy cannot be overemphasized. While hydropower cannot always be depended on for firm power supply, it does offer an economical means of supplying power needed for industries. If Afghanistan is to develop industrlally 1t must develop Its hydropower potential. Because of differences in altitude and sustained flow of rivers from snowmelt, the mountainous areas of the Hindu. Kush that form the backbone of Afghanistan have large potential for hydropower development.

The United Nations (United Nations, 1961) reports that as of 1961 only 1.5 percent of the estimated power potential of Afghanistan had been developed. With the completion of hydropower installations now under construction, there will be an additional 4 percent of the total potential hydropower placed in operation. The following table lists the estimated hydropower potential in kilowatts (kw):

Watershed

Har1

Helmand

Kabul

Kokcha

Kunduz

Miscellaneous

\section{Estimated Potential}

150,000
700,000
750,000
300,000
500,000
100,000
Total $\quad 2, \frac{500,000}{10}$

Total 2, $\overline{500,000}$ 
There are several major hydropower installations in operation at the present time. The following table I/ I1sts the hydropower installations of over 1,000 kw installed capacity:

\begin{tabular}{llllr}
$\begin{array}{c}\text { Map } \\
\text { No. }\end{array}$ & Name & $\begin{array}{c}\text { Date of } \\
\text { Installation }\end{array}$ & $\begin{array}{c}\text { Area } \\
\text { Served }\end{array}$ & $\begin{array}{c}\text { Installed } \\
\text { Capac1ty (kw) }\end{array}$ \\
\hline 1 & Jabulus Seraj & 1920 & Bagram & 1,500 \\
2 & Wardak & 1941 & Kabul & 3,360 \\
3 & Pul-1-Khumr1 & 1943 & Pul-1-Khumr1 & 4,800 \\
4 & Sarob1 & 1957 & Kabul & 22,000 \\
5. & Girlshk & 1958 & Helmand Valley & 2,400 \\
6 & Khanabad & 1960 & Khanabad, Kunduz & 1,400 \\
7 & Pul-1-Khumir II & 1962 & Pul-1-Khumr1, Baghlan 9,900 \\
8 & Darunta & 1964 & Kabul & 11,000
\end{tabular}

Also, there are several small hydropower plants serving spectal needs. The combined capacity of these plants is about 1,000 kw. Two hydropower plants under construction at present, Mahipur and Nahglu on the Kabul River with a combined installed capacity of $111,500 \mathrm{kw}$, will serve the Kabul area. Many potential hydropower sites are being considered for future development. Among the more important are a 120,000 kw station at Kajaka1 Reservolr on the Helmand River; a 13,000 kw station on the Harl River 80 miles east of Herat; a 4,500 kw station on the Kokcha River near Kowajoghan; and possibly six additional stations on the Kunduz River near Baghlan.

If Extracted from a report entitled, "Coordinating the Development of Afghanistan's Energy Resources", by Enar Eskilsson, 1965, United Nations. 


\section{Irrigation}

Currently, about 85 percent of the people in Afghanistan derive their living from agriculture. Because of the scant rainfall during the growlng season most irrigated crops are dependent on water in streams released from storage in the snow pack of the Hundu Kush. Irrigation from streams has been practiced for many centuries in a primitive but effective manner, and the remains of ancient irrigation works can be seen in many parts of the country.

The RGA is taking rapld steps forward in the development of irrigation in new areas and in the improvement of existing systems. The following table (United Nations, 1961) shows the major projects that will bring newly developed lands under irrigation:

\begin{tabular}{lllr} 
Project & Province & $\begin{array}{l}\text { River } \\
\text { Source }\end{array}$ & $\begin{array}{r}\text { Hectares } \\
\text { Irrigated }\end{array}$ \\
\hline Helmand Valley & Helmand & Helmand & 60,000 \\
Nangarhar & Naghahar & Arghandab & 31,500 \\
Alchin & Ghazni & Ghazni & 15,000 \\
Shibarghan and Andko1 & Fariab and Jozan & Shirin Tagao \& Sarepul 20,000 \\
Zardsung & -- & - & 3,000 \\
Gowgan & Herat & Hari & 4,000
\end{tabular}

Many of the present canals do not carry sufficlent water for full irrigation of all land served by the canals. The following table (United Nations, 1961) shows the major canals on which improvements are being made or are scheduled to be made in the near future: 
Ajmir

Arch1

Gouhargan

Charhardarah

Nagir

Allabad

Sharawan

Badak

Kohestan
Kunduz

Kokcha

- -

Kunduz

- -

Kunduz

Oxus

Kabul

Panshir
12,000

14,000

3,000

32,000

12,000

8,000

28,000

5,200

3,200

It has been estimated (United Nations, 1961) that there are about 50,000 million cubic meters of runoff each year of which about 30,000 million cubic meters could be impounded. There are about 5.5 million hectares of land under irrigation out of a total of 14 million hectares classified as arable. Only about half of the irrigated land is cropped each year because of poor soll conditions caused by farming practices of the past. Furthermore, some canal systems are unable to carry sufficient water during critical perlods of low streamflow. The construction of diversion dams or barrages to impound water would prevent damage to canal intakes during floods and maintain water levels above canal intakes. 
Flood Control

Although Afghanistan is mostly semi-arid to arid, some areas are flooded from intense rains almost every year. Most damage up to the present has been confined to the flooding of low-lying agricultural lands and villages. As the population grows, however, with increasing intensity of settlement more and more damage to industry, irrigation works and urban areas is likely to follow unless control measures are developed.

A flood can be defined as any river discharge in excess of the normal channel capacity. In Afghanistan, minor spring floods that inundate crop lards are accepted as a way of life, and in many places are considered beneficial because of the moisture and rich river silt that is added to the land. Occasionally, however, there are major floods that cause great damage. In the spring of 1965, the lower Helmand River Valley was serlously flooded because above-normal ralnfall caused loss of control at Kajakal Reservoir, and many villages suffered great losses of crops, livestock and homes. Gaging station records show that 1939, 1949, 1956, and 1957 were years of major floods in the Helmand River Basin. A British river survey (1903-05) indicates that 1885 and 1903 were years of major floods also. None of the major existing reservoirs have been designed with provision for flood storage. On the Arghandab River, the annual runoff is often not much greater than the storage capac1ty of Arghandab Reservoir, and therefore when the reservoir is filled in the spring, little capacity is left to store heavy runoff late in the season. At Kajaka1 Reservolr, moreover, the average yearly discharge is several times greater 
than the storage capacity of the reservolr. Through proper operation, downstream flooding could be prevented durling most years, especially if gates were installed on the spillway. Gaging station records from which a study of flood magnitudes and frequencles could be made are not available for most of the country. On the Helmand River where the longest periods of record are, records are not long enough nor is station density great enough to define flood frequencies. 


\section{Water Supply}

The municipal water supplies for most towns and villages come from open ditches (Jueys) and shallow wells. The city of Kabul has the only municlpal water-supply system and this comes from deep wells. Only part of Kabul. Is served by this system, and the remainder of the c1ty depends on shallow wells, both public and private, and on jueys that divert water from the Kabul River. In some parts of Aghan1stan where topographic ana geologic features are favorable, water is obtalned from the "kharez" or infiltration gallery. This water is usually of good quality and uncontaminated. The amount of water available per kharez is limited in quantity and usually is considerably less than I cublc foot per second. Most shallow wells cannot be considered safe, because of contamination from sept1c tanks or from raw wastes on the land surface. Many surfacewater supplies are contaminated from these same sources. Aside from chemical treatment, the best sources of uncontaminated water are from the high mountain streams for cities close to those areas, and from deep wells for those in the lowlands.

Adequate gaging-station records are needed for the development of munlc1pal supplies from rivers, not only for service to the people of municipalities, but also for supporting industries. Muncipal supplies are also used for abatement of pollution, for sanitary systems, and for municlpal services such as fire-flghting, beautification and recreation.

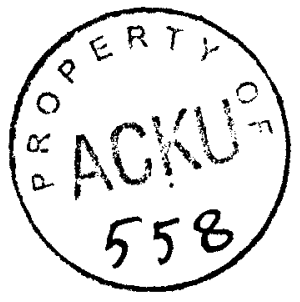




\section{International Rivers}

Almost all major rivers that rise in Afghanistan flow across a border into an adjacent country. One river, the Kunar, rises in Pakistan and flows into Afghanistan where it joins the Kabul River. The Oxus River, where it forms the border with the USSR, has inflow from both the USSR and Afghanistan. With this complex of flow between countries, water records are needed as a basis for international water agreements. At present (1966), both Afghanistan and Pakistan are bullding large Irrigation projects on the Kabul River. Afghanistan and the USSR are developing Irrigation projects that will develop water from the oxus River or 1ts tributarles. Without data to establish the historic flow of these rivers and to measure water use in projects, future equitable allocation may be difficult or impossible. 


\section{Water Law}

According to Hirsch (1959) Afghanistan legal matters pertaining to water utilization are handled on the local level, informally by customary law and, in most of the country, formally according to the Hanefite school of Sunni Islam. Mr. Hirsch, a student of water law, was one of the USADD Misbion Program Officers at the time of this writing. Neither Mr. Hirsch nor the authors have knowledge of any change since Hirsch's. findings of 1959, although there has been an effort undertaken by the RGA, through the UN Economic Commission for Asia and the Far Fast (ECAFE), to establish a modern water code and water law.

Regardless of whether water is apportioned under tribal law or by moderm laws and regulations, the governing agencies cannot make just and equitable distribution without basic data. Such data become increasingly important as water use passes from the relatively simple village irrigation and Iivestock watering use of the past to the allocation of water for large developments in power, irrigation, and industry. 
Surface-water investigations in Afghanistan at present (1966) are chiefly directed to collecting data for specific projects. Until 1963, the activities of USAJ advisors were almed at gathering hydrologic data for the Helmand River basin, and after that time, the work was extended to Include the Hari and Adraskand River basins where land, water and hydropower feasibility studies were begun under UN sponsorsh1p in 1960 .

The WGHM began studies of the Kabul River in 1958 for hydropower and irrigation development. By 1962 they had extended their activities to the Matun River basin in the east, and for a short while, to the Kunduz River in the north. Both of these rivers have irrigation projects planned or under construction.

The WSSD established several stations on the Oxus River and Its tributarles under the technical guidance of USSR technicians. A part of this work hydropower and irrigation studies are being made in the AmuPandj area of the Oxus River and irrigation studies are being made on all. the Oxus River tributaries, with the exception of the Kokcha River.

All the data collected by the WSSD under the guidance of USADD and WGHM technical assistance have been analyzed and tabulated through the 1964 water year. A compilation of data for the Helmand River basin through water year 1960 has been published (Brigham, 1964) by the U.S. Geological Survey. Hydrologic year books have been prepared by the WGHM team for each year from 1960 to 1963. Data collected on the Hari, Adraskand, and Farah Rivers by UN Technicians have been published in a report by the UN 
and some of the data have been recomputed by the WSSD to USGS standards. Data collected by other technical ald missions has not been made avallable to the WSSD at the present time.

With but few exceptions, all gaging stations that have been established by the WSSD under the guldance of the varlous technical aid missions are still in operation (see table 3). 
Evaluation of Surface Water Data Collection Program Organization

Central Agency--Prior to early 1963, the collection of surfacewater data was divided among various Ministries concerned with water projects. In March 1963, the WSSA was organized to assume responsibility for water and soil resources under the leadership of President Mir Mohammad Akbar Reza (who was also Deputy Minister of Agriculture) until March" 1966. At that time, the WSSA was made a department (WSSD) of the reorganized Ministry of Agriculture and Irrigation. Mr. Reza was appointed Minister of Agriculture late in 1965. The WSSD is presently (1966) headed by Vice-President Juma Mohammad Mohamadi. The Surface Water Hydrology Section of the department is headed by Director General Ghulam Sham, now (1966) on military leave.

The Surface Water Hydrology Section has its headquarters in Kabul wth field offices in Kandahar and Kunduz. The Kabul office is divided into two groups, one group receiving technical assistance from US AID and the other group receiving technical assistance from WGHM. The Kandahar field office receives technical assistance from US ADD. The Kunduz field office is considered by the Military to be a direct branch of the Kabul office and is operating in a region of the country where the prime technical assistance comes from the USSR. 
Hydrologic Teams--A description of the hydrologic teams working in Afghanistan has been given the section on "Hlstory". As concerns the collection of basic water data, the teams operate primarily in the manner in which they were trained by their parent organization. In the case of the US AID technicians, the work is performed much along the Iines of U.S. Geological Survey methods. In the case of WGHM technicians, the work is performed to standards of the Federal Republic of Germany. This has not created major problems between the teams, because-both are composed of individuals who understand basic hydrologic principles, but It has led to non-standarization in teaching and training of Afghan counterparts.

- In 1964, a committee composed of representatives from each technical mission and the WSSA was formed to meet regularly and set policy on standards and methods to be used in Afghanistan. The comittee recognized that the basic methods of all teams had merit and agreed that Afghanistan should adopt the best elements from each method. It was also decided to adopt the metric system for all expressions of measurement, and the English language for the preparation of reports. 


\section{Present Gaging Station Network}

The present (1966) gaging-station network consists of the following number of stations grouped according to the office and technical assistance group under which they are operated:

\begin{tabular}{lr} 
Kabul (US ADD) & 13 \\
Kabul (WGHM) & 18 \\
Kandahar (US ADD) & 14 \\
Kunduz & 20 \\
\hline
\end{tabular}

Total 65

Existing gaging stations are shown on the map (fig. I) and are described In more detail in table 4. In addition, there are several canal and reservoir stations, some of which are operated by the WSSD and some by the operation and maintenance departments of the irrigation projects.

Because all the gaging stations now extant were installed to obtain information related to specific projects, no attempt has yet been made to establish a system of primary and secondary gaging stations that would give an overall plcture of the general hydrology of Afghanistan, and that could be used for future planning of projects not yet foreseen. Because of the small number of gaging stations in operation and their specialized nature, the present network is not capable of supplying the data needed for future development. 


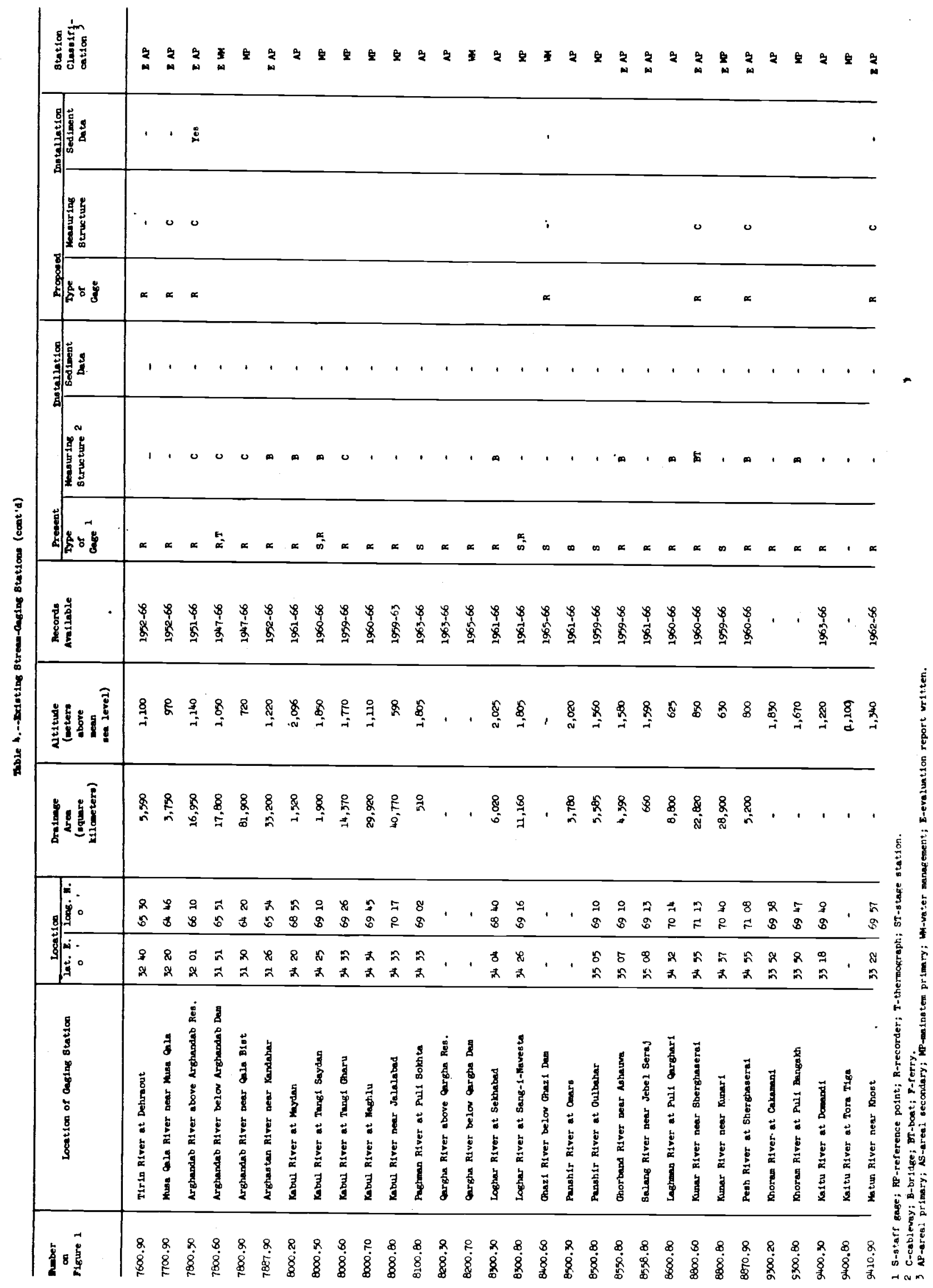


Fleld Work

Because of the dispersal of hydrologic work among various offices operating under different technical assistance programs, it is difficult to evaluate the overall effectlveness of the fleld work.

In the US ATD-supported offlce at Kandahar, there has been a good record of field work accomplished, both in frequency of trips to obtain necessary data and in the quality of the data obtained by Afghan techniclans - all a reflection of the many years of effective logistic support and of training of techniclans at this office. The US ADDsupported office established in 1964 at Kabul, has not yet operated effectively owing to rapid turnover in trained Afghan personnel and IImitations in logistic support. 


\section{Office Work}

An overall evaluation of the work is difficult to make because of the dispersal of offices. In Kandahar, work has progressed falrly well, but much training is still needed beyond the point of simple computation of gage-helghts and discharge measurements. The evaluation of stagedischarge relations is beyond the capabilities of most Afghan technicians at present, but some U.S. educated Afghan engineers are making good progress along these lines. In the Kabul office, 2 years of training has not yet produced techniclans capable of elementary computation of gage-helghts. The only stralght-forward computations of discharge measurements can be handled at present. 
Recommendations

Organization

For the development and management of Afghanistan's water resources It is important that all information and data be available to those in need of 1t. Only through an autonomous organization can this be done. In November 1961, Mr. George C. Taylor, Jr., Chlef of the Forelgn Hydrology Section, U.S. Geological Survey, visited Afghanistan and pre- pared a basic proposal for such an organization. On the basis of his recomendations, a start was made in the proper direction in March 1963 with the organization of the Water and Soll Survey Authority. This organlzation was discontinued as an autonomous body in early 1966 and absorbed as a department in the Ministry of Agrieulture and Irrigation. The basic reasoning of $\mathrm{Mr}$. Taylor's recommendations is still valid, however, and as qualified personnel become avallable to staff a national organization, his recomendations should be given serlous consideration. In the five years that have passed since Mr. Taylor wrote this paper, the value of his recommendations has been emphasized by the problems assoclated with the multitude of agencles offering technical assistance. Real progress w1ll not be possible until all activities are brought under one head, and a standard system of procedure 1s adopted. Mr. Taylor's paper, outlining the general. structure of a body for coordinating and policy. making; an institute responsible far hydrologic research, surveys, and data collection; and a control agency for apportioning water resources, adjudicating water disputes, and issuing licenses and permits, is presented in its entirety in the Appendix to this report. 
Proposed Gaging Station Network

The present (1966) gaging station network consists of 65 streamgaging stations. According to a system of determining gaging station density by population and climatic conditions presented by Langbein (1959) a network of 0.2 station per 1,000 square kilometers should be considered as a minimum program. On this basis, Afghanistan should have a network of no less than 127 stations. Under this minimum program, nearly all stations would be primary stations. No provision is made for temporary ( 5 to 8 years) stations to obtain information for specific purposes such as development of irrigation or hydropower, determination of heavy sediment loads, or analysis of saline water. With Afghanistan rapidly developing its agriculture and hydropower, the minimum requirement should be ralsed to about 0.3 station per $(1,000)$ square k1lometers. At this density level, Afghanistan would require 190 streamgaging stations.

Primary gaging stations--A primary gaging station is one located where the discharge of a river cannot be obtained in any manner other than by direct measurement. No other gages in the same or nearby basins w1ll give satisfactory results elther by the sumation of two or more stations or by a correlation of discharges. According to Langbein's minimum program classification, About 120 gaging stations will have to be primary stations.

Secondary gaging stations--Secondary gaging stations are those located In areas of short-term interest, or whose records correlate within acceptable limits with those of a primary station after a relatively short period of operation, usually about 5 years. When the purpose for which a secondar 
gage was installed is accomplished or an acceptable correlation is defined, the station is moved to a new site.

There is no formula to determine the number of secondary gaging stations. The desired density, the number of sites of short-term interest, the climatic, topographic, and geologic factors that determine the correlation between sites, are all items that influcence the number of secondary gaging stations. When the minimum requirements for primary, water-management, reservolr, and benchmark stations have been met, the secondary network can be planned on the basls of need balanced against economic resources.

Water Management Stations--Water management stations are those used to obtain discharge information for operation of reservoirs, irrigation systems, hydropower plants, municlpal water systems, and other hydraulic Installations. Generally speaking, each such installation w11l require an Inflow and an outflow station. On large complex systems more than one gage may be needed to record inflow.

Partial-Record Stations--Partial-record stations are those used to determine the discharge during critically high- or low-flow perlods. For example, an irrigation system is more dependent on minimum flows than on average or high flows; a flood-control project would require information pertaining to flows large enough to cause flooding; an industry might operate only during the part of the year when raw products are available. The number of stations required would be determined by the project needs. 
$\underline{\text { Reservoir and Stage Stations--Reservoir stations are used to determine }}$ the reservoir contents at any elevation of the reservolr surface. For planning and operating, it is important to know the volume of water Impounded because of its effect on cropping practices, power generation, and flood-control releases.

Stage stations are used to determine the elevation of a river above a reference point for forecasting flood crests and for navigation. The number of each type of reservoir or stage station required depends on the number of reservoirs and the need for flood waming and navigation information.

Benchmark Station--Benchmark stations are used to determine the amount of Influence man's activities may have on a river basin. In the normal course of operation of a gaging station network, a long-term change in a river's flow can be readily detected, but the cause of the change is not always evident. Many of man's activities will have the same effect on a river basin as w1ll a change in climatic conditions. Quite often a change in planning will result if it is shown that previous development activities have had a deleterious effect on the river flow.

Benchmark stations are located on small drainage basins of 1 to 10 square miles and in wilderness areas where the likelihood of future influence by main is nil. Such stations are generally operated on a nonroutine basis and with a minimum of equipment. A complete inventory of all basin and river characteristics is made including geology, topography, ground cover, soll types, river cross sections, meander patterms, streambed gradients, and many others. Periodically, the initial inventory is 
checked against current conditions to see if any changes are apparent.

Three benchmark stations probably would sufflce for Afghanlstan: one in the northern section, one in the central plateau, and one in the southerm desert area. Because of the qualifying conditions it may not be possible to find suttable drainage basins in all these regions.

The proposed stream-gaging stations are show in table 5. Approximately 40 of these sites have been visited and reconnalssance reports have been written. Another 20 sites have been selected by map reconnalssance and will be visited in the near future. 


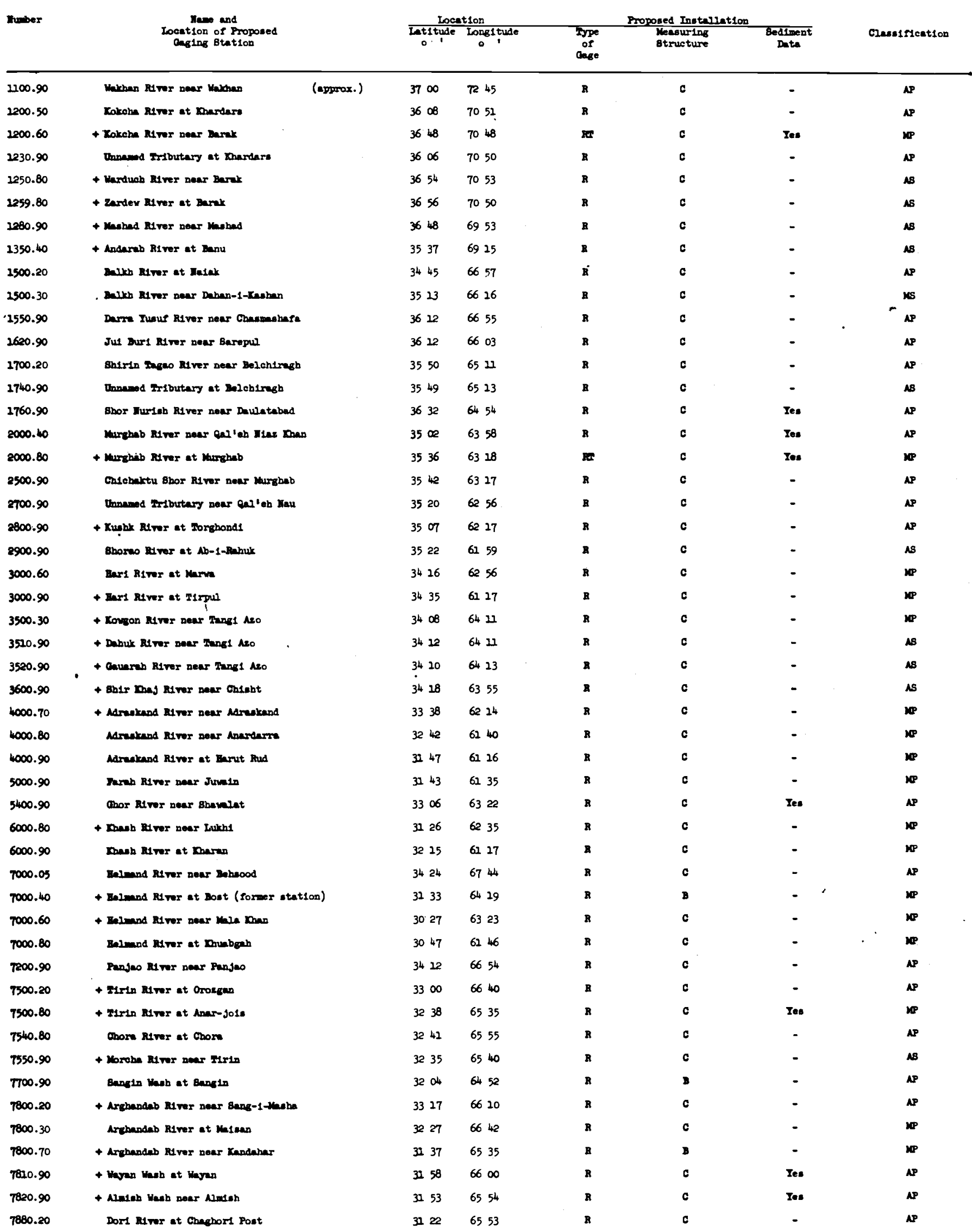


muble 5.--Propoed Atron-anging Btatione cont'd

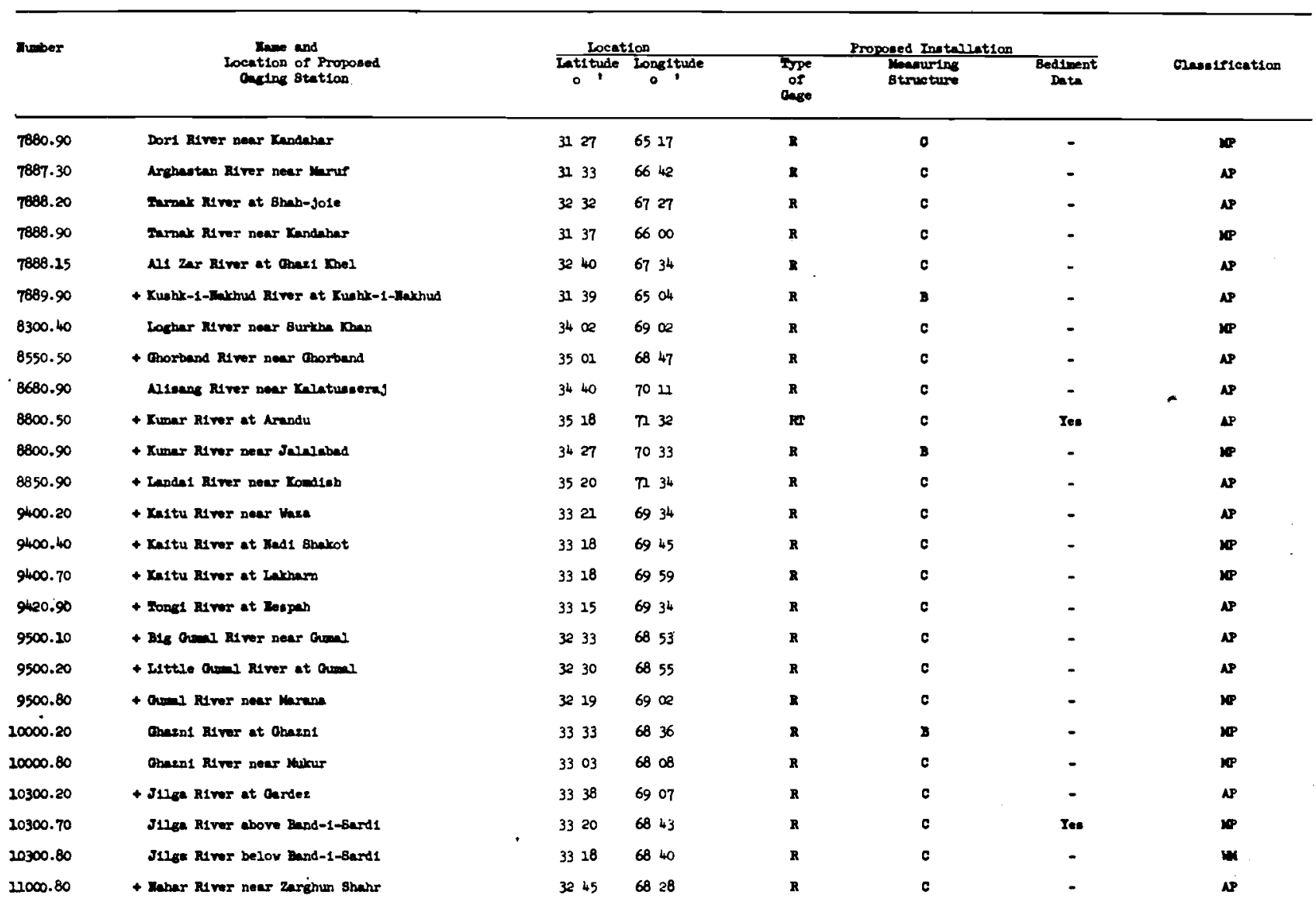

Zype of Oeget R-veter-etege recorder, T-rwecording the rmograph

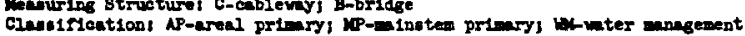

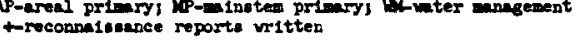




\section{Procedures and Standards}

Fleld--A comprehensive "Hydrology Training Manual" that describes procedures and standards for basic stream gaging has been complled by the author and used in the WSSD since 1964. The training manual, adapted from the U.S. Geological Survey Stream Gaging Manual, was modifled to f1t conditions in Afghanistan and was rewritten in 1966 to include sections previously omitted. This manual has been duplicated by US ADD/Kabul for use in Afghanistan. The procedures and standards described in the manual are recommended for adoption by the WSSD. The information contained in the manual covers all phases of basic stream-gaglng work except for sedimentology and surveying. These subjects are more complex than basic streamgaging and the reader is referred to the approporlate reference listed at the end of this report for recommended procedures and standards in these subjects.

There are several technical ald missions in Afghanistan and each mission uses the procedures and standards of its parent organization insofar as posstble. People have a natural tendency to use the methods they are most famlliar with, but these methods may not always be the best under different sets of conditions. For example, the European system of computing river discharge by the graphical method is very good in an area, where the utilization of the water has been developed to a high degree and there is an abundance of well-trained techniclans. However, in an arid country in the early stages water-resources development, the time and expense devoted to such complex computations could be better spent in gaining broader coverage of field data, rather than attempting to refine the avallable data to a degree unwarranted by a limited number of trained technicians. 
There is also a tendency among some of the technical ald missions to measure one hydraulic parameter more accurately than others. For example, the relation of the river stage to the river discharge is basic to computing the mean dally discharge. Some missions measure the mean dally river stage very accurately by means of an automatic water stage recorder. On the other hand, they may measure the river discharge at flows higher than wading stage, by unproved indirect methods. Again they may attempt to relate the discharge measured at a low stage to that of a high stage by adjusting the area and velocity readings through a curve of relation. This procedure can lead to erroneous results because of unknown factors both in the measurement at the low stage and in the channel conditions at the high stage.

One of the major reasons for failure to measure the river discharge at higher stages is the lack of the necessary cableways to make highdischarge measurements. It is false economy to assume that it is not necessary to spend money for cableways, if the discharge can be computed Indirectly, because indirect measurements are often erroneous. If later project design is based on incorrect data, then the resulting works will be elther too large or too small for the avallable water supplies. Either over-or under-design is economically unsound. Also, the cost of a cableway is but a small fraction of the cost of even. a small irrigation or hydropower installation. Because it wlll provide the means to obtain adequate data for properly design hydraulic works, a cableway will pay for 1tself many times over. 
Office--The procedures and standards used for office work and trainIng of Afghan personnel are contained in a manual compiled by the project engineers over a perlod of years. This manual was orlginally written by Mr. I. F. Snell, revised by Mr. I. A. Heckmiller, and is being completely rewritten, updated, and expanded by Mr. V. J. Latkovich at the present time. This manual is recommended as the standard text for office computations.

Special investigations--Special investigations of river hydrology are essential to a well-rounded water-resources plan for appraisal and develop. ment. Such investigations can be divided into two classes: (I) those for a specific purpose or project, and (2) those that contribute to the overall knowledge of the hydrology of a basin or region. In Afghanistan, all special investigations up to the present time have been carried on for specif1c purposes or projects.

Special Investigations can be made elther by contract specialists hired for the purpose, or by the agency responsible for the operation of a national hydrology program. In Afghanistan, there have been in the past a large number of contract specialists or teams from international organ1zations carrying out these investigations, often overlapping or duplicating one other to a considerable extent. Also, many special investigations have been based on too little factual data, because of the lack of an adequate stream-gaging networks and records, and the subsequent reports have been in error in certain respects. Too often, there has been a tendency among these groups to base interpretations on very skimpy data, and to assume unverified hydrologic and meterologlc relations. 
The staffing patterm presented in the next section of this report, Includes a hydrologic studies section in the headquarters office. It Is recommended that this section be organized and trained as rapidly as qualifled personnel become avallable. Only through the use of such a section can the special investigations be carried on with direction and purpose. This w1ll result in substantial savings in trained manpower and in forelgn exchange both of which are critical in Afghanistan. 


\section{Personnel}

The present Surface Water Hydrology Section, divided as it is among offlces recelving guldance from different technical assistance missions, can only continue in its present fragmented operational pattern, unless some adjustments are made. If it is not feasible to operate under direction of one technical assistance mission, then it is recommended that the RGA either hire an expert foreign hydrologist to coordinate the activities of the varlous technical assistance missions. or that it select the methods and procedures considered most approprlate to nationwide needs and incorporate them in program agreements with the varlous technical assistance missions. The following staffing pattern and organization chart is suggested to provide the necessary leadership and to define areas of responsibility.

Size of staff--Assuming that optimum development of a gaging station network w111 result in 190 gaging stations, it w1ll take a staff of about 50 professional, subprofessional, and clerical workers to operate the network. This represents about one worker for every four gaging stations and Includes about one professional to two subprofessional workers.

Disc1plines--Flgure 2 shows the recommended organization of the Surface Water Hydrology Section of the WSSD. 


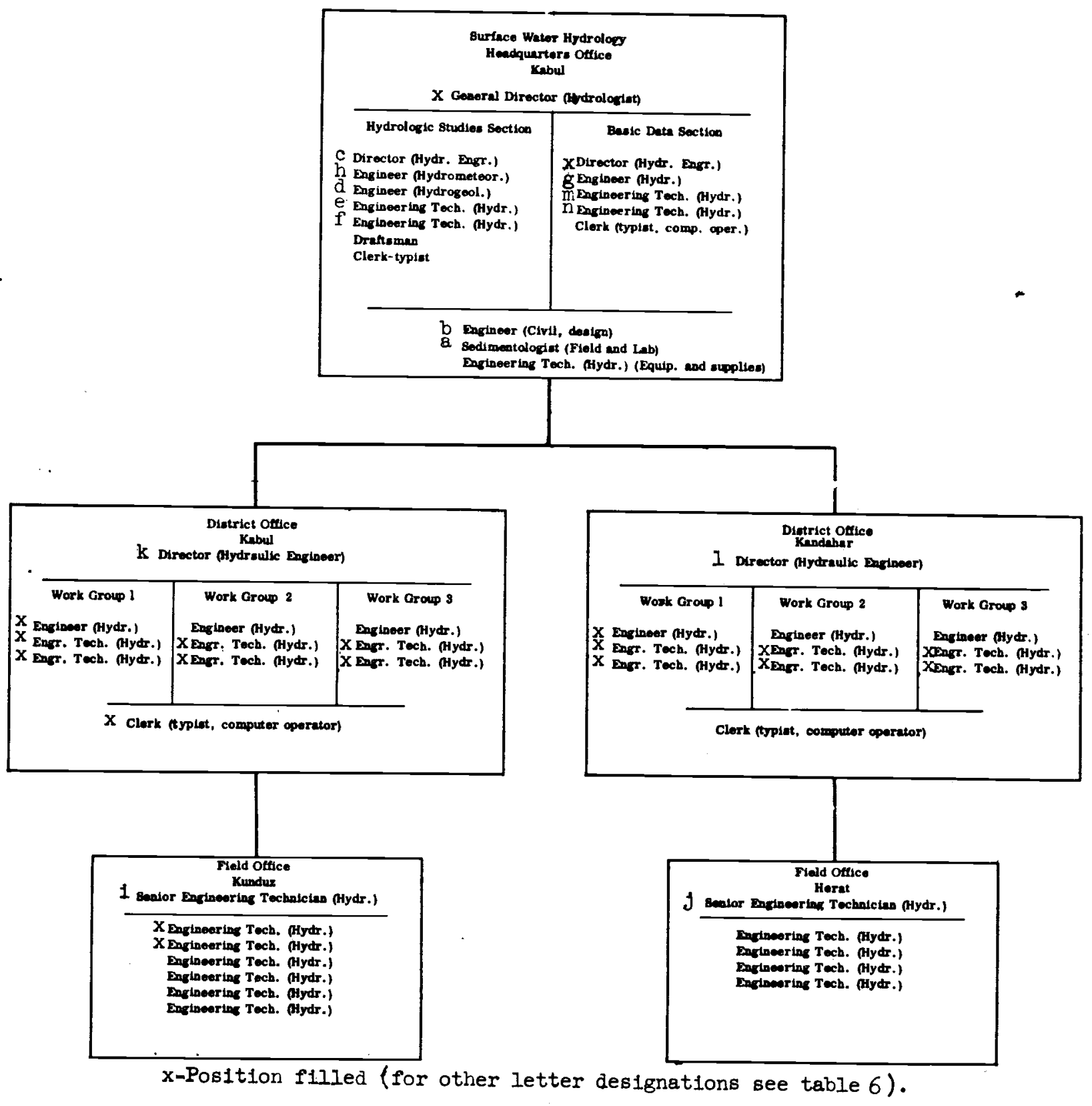

Flgure 2.--Recommended staffing pattern 
The following is a summary of the recommended positions:

Professional

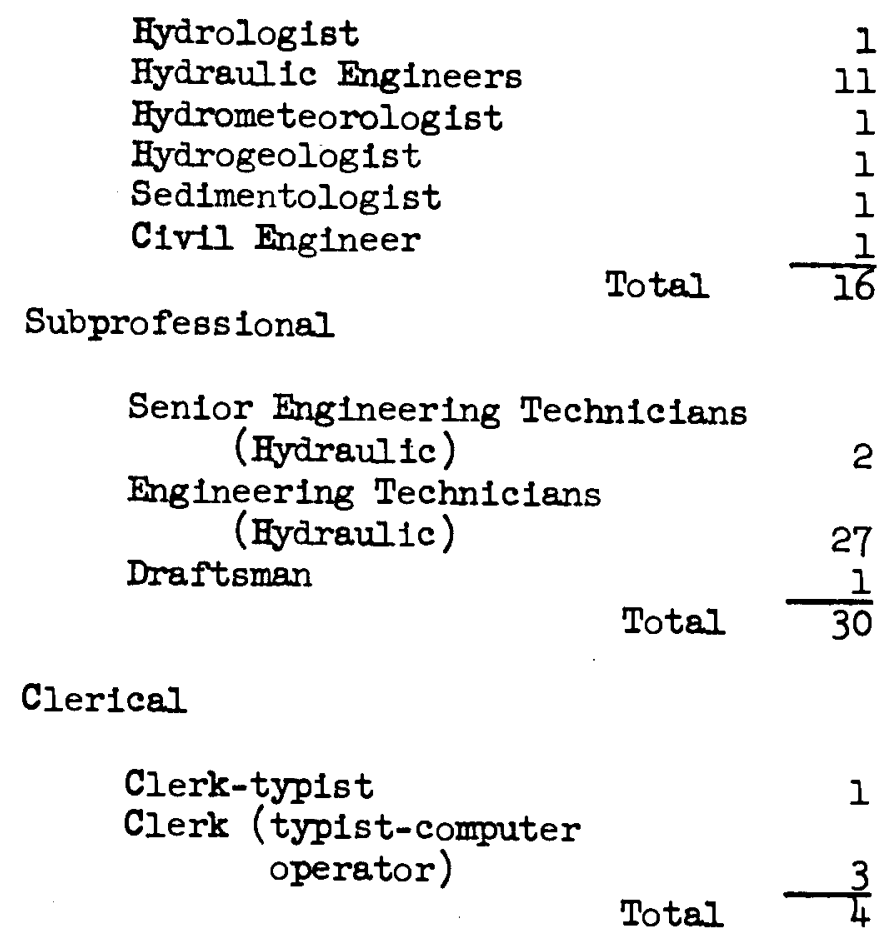

Present staff--The present staff consists of about 25 people of which only five have had college training. Of the college-trained men, one has recelved a degree from an American university, and the others have recelved degrees from Kabul University. Two men have recelved additional schooling In the United States but did not qualify for the B.S. degree. The work experlence of the college-trained men ranges from zero to 5 years.

The subprofessional workers vary considerably in education and experlence. Some are technical school graduates, others have only a sixthgrade general education. The work experlence ranges from zero to about 17 years, but in general the most educated are the least work-experienced. 
Participant training--To fill the positions recomended in the staffing pattern, it will be necessary to provide academic training at graduate level or speclal course work at approprlate universities, or a practical course of in-service training at U.S. Geological Survey fleld offices in the United States. Table 6 shows the recommended participant training program. The letter keys in the left-hand column of table 6 are entered in the staffing pattern (fig. 2) to show where these participants will fit.

In-service training--Training programs of an in-service type must be organized and given to all employees at all levels. The first such course entitled, "Hydrology Training Manual No. 1, Basic Streamgaging," was prepared by the author in 1964 and revised, updated, and duplicated by US ADD/Kabul in 1966. This manual covers all phases of basic streamgaging including methods, procedures, equipment, operation, safety, and basic offlice procedures.

A second training manual covering more advanced office procedures is in preparation and must be put into use as fast as the capabilities of the Afghan employees allow. Most training manuals avallable through the U.S. Geological Survey, United Nations, and other groups have to be modified to fit the conditions of Afghanistan and the background of the Afghan technican. Because of language difficulties, standard English tests on hydrology are generally not sultable. For this reason, it is recomended that the training manuals be translated into Farsi. This would greatly enhance their value in training the subprofessional employee. 
Table 6.--Recommended participant training program

FY

$1966 / 1967 / 1968$ / / 1969 / 1970 /

a

b

c

d

e

f

g

$\mathrm{h}$

1

$j$

$\mathrm{k}$

1

m

n
$\operatorname{xoxxXX}$ (under training)

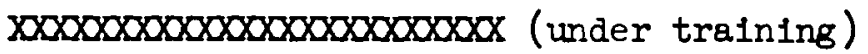

$\operatorname{xx} \times x \times x \times x \times x \times x \times x \times x \times x$ (nominated) $X \times X X X X X X X X X X X X X X X X$

$\operatorname{xxxxxxxxxx}$

$\operatorname{XxXXXXXXXX}$

\section{$x \times x \times x \times x \times x \times x \times x \times x x x x$}

$\times x \times x \times x \times x \times x \times x \times x \times x \times x$

$\operatorname{xxXXXXXXX}$

$\operatorname{xx} x \times x \times x \times x$

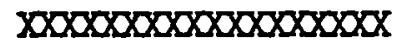

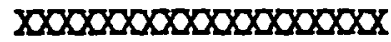

$\operatorname{xxx} \operatorname{xx} x \operatorname{xix}$

$\operatorname{xxx} \times x \times x$
(24)

$(18)$

$\left(\begin{array}{l}10) \\ 10\end{array}\right)$

(18)

( 9)

(18)

(18)

$\left(\begin{array}{l}8) \\ 8\end{array}\right)$

\footnotetext{
a Solls Classification

b Civil Engineering (Hydraulic)

c Special Academic (Hydrology)

d Special Academic (Hydrogeology)

e USGS In-service Program

$f$ USGS In-service Program

$g$ Special Academic (Hydrology)

$h$ Special Academic (Hydrometeorology)

1 USGS In-service Program

$j$ USGS In-service Program

$k$ Special Academic (Hydrology)

1 Special Academic (Hydrology)

m USGS In-service Program

$n$ USGS In-service Program
}

Each letter indicates a participant 
Hydrologic--The hydrologic equipment and supplies needed to operate a gaging station network are described in Hydrology Training Manual No 1. The project equipment and supplies currently (1966) on hand or on order are sufficlent to operate the recommended network.

The kiggest problem with equipment in the past has been the lack of maintenance. Attempts have been made to assign responsible personnel to a maintenance program but this had little success because of the frequent transfer of trained individuals who understand the workings of the equipment. The staffing pattern calls for one englneerlng technician who will have charge of all equipment. Th1s man should be thoroughly trained in the maintenance of all hydrologic equipment and be responstble for 1ts upkeep and repair.

Transportation--Suitable vehicles for transportation of field personnel to gaging station sites for the timely collection of data have not always been avallable when needed. Rough travel over all kinds of terrain demands that vehicles be in first-class condition and that an adequate supply of spare parts be avallable for immediate repairs. Often valuable data are missed because of lack of transportation due to breakdown or insufficient fuel.

All vehicles assigned to the Surface Water Hydrology Section should be for 1ts exclusive use. Experience has shown that lack of authority over vehicles has led to a lack of maintenance. In surface-water hydrology, it is often necessary to make emergency trips to repalr on-site stream-gaging 
equipment or obtain data avallable only during periods of stormy weather. Without control over the vehicles, these data can be lost forever.

Maintenance--An adequate supply of hand tools and equipment for effecting repairs at gaging stations should be maintained in the warehouse at all times for emergency use, and each field man should be supplied with a tool kit for making on-the-spot repairs. The great distances involved and the difficulties of travel can make even minor repalrs costly" if the field man has to returm a second time.

Routine maintenance of water-stage recording devices can be accomplished with a few simple hand tools. To clean stilling wells and correct cable sag, however, may require tools not ordinarily carried by the fleld man. Therefore, for complete maintenance, a regular system of inspection should be established whereby the fleld man notes on special forms what maintenance is required. The maintenance crew can then take the necessary equipment to do a proper job.

Office--Although there is a good supply of office and drafting equipment avallable on the local market, the WSSD is currently (1966) lacking In the most basic implements needed for routine drafting and office work, Including operable typewriters and calculators. There are two Ozalid machines in the WSSD. One is a large-capacity production machine and the other is a 16-inch table model. Ne1ther machine can be used because of the need for a varlable voltage transformer. Such simple but necessary Items as pens and drawing ink, scales, trlangles, and T-squares also have been in short supply. Good quality rag-base paper with a long storage 
Iffe is not available through government supply sources although it can be purchased on the local market. If the data are to be computed accurately and recorded in an acceptable manner, the office machine must be maintained in an operative condition and necessary supplies furnished to do the job. Much valuable data wlll be lost over the years by use of short-lived infertor inks and paper. 


\section{Publications and Library}

Basic data--At the present time, the basic data are not being published or distributed on a periodic basis. The dally gage-heights, daily discharges, monthly means, maximums and minimums, and the instantaneous yearly maximums and minimums are being entered on data sheets for each station from which prints are made as requests are recelved. For a few years, the West German Hydrologic Mission (WGHM) was printing a hydrologic year book containing essentially the above types of information plus a duration curve for each gaging stating under their purvlew. The data collected In the Helmand Basin up through 1960 were complled and published In a duplicated report (Brigham, 1964) by the U.S. Geological Survey.

The data collected by technical aid groups, other than the US AID and WGHM groups, are not being reported to the central office. These data are being taken out of the country and presumably w11l be avallable in report form at some future date.

The recommended form of publication is a hydrologic year book simflar to that formerly published by the WGHM and should Include data from all gaging and meteorological stations in Afghanistan. The duration curves as presented by the WGEM should be modified to have one curve show the percentage of total time that a specific discharge has been equaled or exceeded rather than single-year curves that show the number of days during the year a specific discharge has been equaled or exceeded. Ihis modification would make the data more useful for long-term analyses. 
Iibrary--The library should contain a section where all hydrologic and meteorologic data collected in Afghanistan (and adjoining regions If avallable) will be in a central file and accessible for use by interested parties. The library should contain all the raw data as well as any analyses, maps, tables, graphs, reports, and statistical compllations that have been made. The library should also contain a section of selected text books, periodicals, and publications of hydrological organizations. The sclence of hydrology and the development of new techniques are advancing rapidly; constant study is necessary to keep abreast of current activities. 


\section{References}

Brigham, Robert H., 1964, Compllation of Hydrologic Data, Helmand River Valley, Afghanistan through September 1960, U.S. Geol. Survey Open-F1le Report, 236 p.

Corbett, D. M., and others, 1943, Stream-Gaging Procedure: U.S. Geol. Survey Water Supply Paper 888, 245 p.

Davis, R. E., and Foote, F. S., 1953, Surveying, Theory and Practice, 4th ed., McGraw-H111, New York, 1021 p.

Grover, N. C., and Harrington, A. W., 1943, Stream flow, lst ed.: John W1ley Co., New York.

Hirsch, Abraham M., 1959, Water Iegislation in the Middle East: American - Jourmal of Comparative Law, vol. 8, no. 2, p. 168-186.

Horton, R. E., 1907, Weir Experiments, Coefficlents, and Formulas: U.S. Geol. Survey Water Supply Paper 200, 195 p.

King, H. W., 1954, Handbook of Hydraulics: McGraw-Hill Co., New York. Langbe1n, W. B., 1959, Hydrologic Data Networks of Extrapolating or Extending Hydrologic Data, in Hydrologic Networks and Methods, UN Flood-Control Series no. 15, WMO, p. 13-41.

Langbe1n, W. B., and Iser1, K. T., 1960, General Introduction and Hydrologic Definitions: U.S. Geol. Survey Water Supply Paper 1541-A, 29 p. Iinsley, R. K., Jr., Kohler, M. A., and Paulhus, J. I. H., 1949, Applled Hydrology: McGraw-H1]1 Co., New York.

Iyon, G. I., 1915, Equipment for Current-meter Gaging Stations: U.S. Geol. Survey Water-Supply Paper 371, 64 p.

Mesnier, G. N., and Iser1, K. T., compllers, 1963, Selected Techniques in Water Resources Invest1gations: U.S. Geol. Survey Water-Supply Paper 1669-z, $64 \mathrm{p}$ 


\section{References cont'd}

Plerce, C. H., 194I, Investigations of Methods and Equipment Used in

Stream Gaging: U.S. Geol. Survey Water-Supply Paper 868, 75 p. Plerce, C. H., 1947, Equipment for River Measurements, Structures for Cableways: U.S. Geol. Survey Circular 17, 38 p.

United Nations Economic Commission for Asia and the Far East, 1956, Glossary of Hydrologic Terms Used in Asla and the Far Easts FloodControl Series no. 10, $38 \mathrm{p}$.

United Nations Economic Commission for Asla and the Far East, 1961, Multiple-Purpose River Basin Development, Part 2D, Water Resources Development in Afghanistan, Iran, Republic of Korea, Nepal: FloodControl Series no. 18, p.

United Nations Economic Commission for Asla and the Far Fast, 1960, Bydrologic Networks and Methods: Flood-Control Serles no. 15, 152 p. United Nations Economic Commission for Asla and the Far East, 1962, Fleld Methods and Equipment Used in Hydrology and Hydrometeorology: Flood-Control Serles no. 22, 127 p.

Wisler, C. O., and Brater, E. F., 1963, Hydrology, and ed.: Wiley \& Sons, New York, $408 \mathrm{p}$.

Ralnwater, F. H., and Thatcher, I. I., 1960, Methods for Collection and Analysis of Water Samples: U.S. Geol. Survey Water-Supply Paper 1954, 301 p. 


\title{
Append1x
}

\section{A National Water Resources Commission}

by

\author{
George C. Taylor, Jr. \\ U.S. Geological Survey \\ Kabul, Afghanistan \\ November 1961
}

Recognizing the great importance of water resources in many facets of Afghanistan's economy and the need for judiclous development and management of avallable water supplies for the general benefit, it is proposed to establish ultimately an autonomous National Water Resources Commission. This body would be composed of a Coordinating Board, for policy making, and a Directorate-General, for Implementation of policy. The Coordinating Board would be composed of the Ministers or their designated representatives from the following Ministries: Planning, Public Health, Mines and Industry, Agriculture, Finance, Public Works. The Minister of Planning or his designated representative would be permanent Chairman of the Board. Implementation and execution of policies promulgated by the Board would be the responsibility of the Director-General of the Commission who would be assisted by three Assistant Directors, one for Water Resources Investigations and Planning, one for Water Resources Development, and one for Water Resources Conservation and Management. The Assistant Directors would have responsibility for guldance and coordination of water resources activities and functions within their respective purviews. 
Appendix (cont'd)

It is not concelved that the Water Resources Commission would be an operational agency but rather a coordinating and policy-making group to review and approve all major water resources projects and programs before operating funds are made available. Operational functions in water resources development and management would continue to be among the "IIne" ministries as is the current situation. However, it is proposed to establish an autonomous Nat1onal Hydrologic Institute which could be attached either directly to the Water Resources Cormission under the approprlate Assistant Director or to the Ministry of Planning. The Institute would be an operational organization responstble for hydrologic research, surveys and data collection and for making such information readily avallable to agencles concerned with water development and management.

In addition an autonomous and operational National Water Resources Control Agency is proposed. The agency would be responstble for overseelng the apportlonment of all water in "declared" ground-water basins, the allocation of surface-water supplies, the adjudication of water disputes, the licensing of well drillers and 1ssuance of permits for well construction, and other conservation and management functions as deemed desirable by the Coordinating Board. The Agency would be attached directIy to the Water Resources Comlssion through the appropriate Asst. Director. 
Appendix ( cont'd $\left.^{2}\right)$

Functional responsibilities of governmental agencles working in National Water Resources Commission

An autonomous National Hydrologic Inst1tute under the survelllance of the Assistant Director for Water Resources Investigations and Planning, would be composed of qualifled hydraulic engineers, hydrogeologists, chemists, mathematicians and supporting personnel. The institute would be headed by a Chief Hydrologist and would be responsible for maintainIng an adequate network of stream-gaging stations on all major river systems in the nation and for compiling, analyzing, and publishing continuing stream-flow data; for undertaking hydrologic and geologic investigations of important ground-water basins and for preparing analytical reports on the quantity, quality and avallabllity of ground-water supplies; for the establishment and maintenance of an adequate network of observation wells to evaluate seasonal and long-term changes in ground-water storage; for systematic inventories of wells, springs and infiltration tunnels (kharezes) and compllation of hydrologic data on sultable forms and maps; for the establishment and maintenance of a hydrologic and water quality laboratory; for the establishment and maintenance of files of hydrologic data and reports for the entire country. Exploratory drilling required for groundwater Investigations would be undertaken by private contract or departmentally by the drilling section of the Afghan Geological Survey (Ministry of Mines and Industry) or designated drilling sections in other governmental agencles. 
Appendix (cont'd

A. The Meteorological Institute would have responsibility for maintaining an adequate network of weather stations for continuing collection of precipitation, temperature, evaporation and other meteorological data essential to proper evaluation of the nation's water resources.

B. Hydrologists of the National Hydrologic Institute in collaboration with soil scientists and land classification experts from the Ministry of Agriculture and Irrigation engineers and engineering geologists from the Ministry of Public Works would have responsibility for undertaking land and water surveys of large river basins prior to major development.

C. The Ministry of Agriculture would have responsibility for supervising the construction of small Irrigation systems including (1) dams and canals and (2) the drilling and equipping of production irrigation wells and provision of power sources for pumplng. In established ground-water 1rrigation development projects.

D. The Ministry of Public Health would have responsibility for supervisIng the construction of public-water supplies including those derived from surface-water diversions and for drilling and equipping public-supply wells and provision of power sources for pumping and water distribution.

E. The Ministry of Public Works would have responsibility for supervisIng the construction of major dams both single and multi-purpose for irrigation, hydropower and flood control and for major canals and floodcontrol structures. Construction of hydropower generation and distribution systems would be the responsibility of the Ministry of Mines and Industry. 
Appendix (cont'd)

F. An autonomous National Water Resources Control Agency reporting to the Assistant Director for Water Resources Management and Conservation would be headed up by a Chlef Conservationist and would have responsibility for licensing well drillers and issuing permits for production wells in "declared" (that 1s, heavily developed) ground-water basins; for maintainIng files of well logs and related hydrologic data; and for the apportionment of water and allocation of water rights to diversions from streams and for Issuance of permits and licenses for same.

G. The operation and maintenance of the canals and diversion works of small surface-water Irrigation systems and of wells, pumps and power sources in ground-water development projects would be the responsibility of the Ministry of Agriculture.

H. The Ministry of Public Works would have responsibility for the operation and maintenance of major dams and canals for Irrigation and flood control. The Ministry of Mines and Industry would oversee operation and maintenance of hydropower stations and power distribution systems.

I. Operation and maintenance of public water supplies and sewage disposal systems and the enforcement of sanitary codes would be under the surveillance of the Ministry of Public Health.

IKriculture-O/AID/REP

LIBRARY

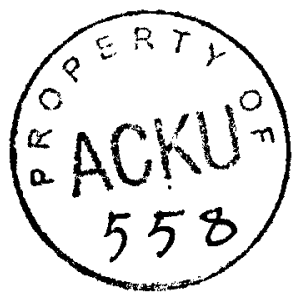


note:

The original material azu_acku_pamphlet_hd1698_a3_w47_1966: page030: Missed. 